\title{
VOLITIONAL ORGANIZATION OF PERSONALITY AS A SUBJECT OF EMPIRICAL RESEARCH
}

\author{
Karina ShamLyan \\ Department of philosophy and psychology, \\ National Forestry University, \\ General Chuprynka 103, Lviv 79057, Ukraine \\ E-mail address: kkst.emovol@gmail.com
}

\begin{abstract}
The article deals with empirical research of stable characteristics of volitional activity. Volitional organization of personality is considered as a system of volitional qualities that are naturally connected in a particular person. Different classifications of volitional qualities and approaches to empirical research are examined. The survey results of volitional qualities of students are investigated. The possibilities of reflexive methods in the research of volitional organization of personality are analyzed.
\end{abstract}

Keywords: volitional organization of personality, volitional qualities, willpower, volitional effort, empirical research, purposefulness.

Nowadays Ukraine is facing terrible ordeals. They increasingly require courage and resilience from all the citizens of our country, serious educational work on formation of moral and volitional qualities of the youth. Psychological research of person's volitional capacity, its structure, and also terms for development and education, is topical under these conditions.

In psychology understanding of will as the ability to consciously achieve the goal overcoming the external and internal obstacles is considered to be traditional; i.e., the necessary features of volitional behavior are the existence of a conscious goal, tangible barriers, and the implementation of efforts to overcome them. In modern research the problem of will is considered as a conscious mental self-regulation of activity and behavior (Ilyin, 2011; Ivannikov, 2010; Kalin, 2011; Smirnov, 2004).

Psychology has accumulated a huge amount of empirical material on peoples' volitional activity that can be grouped around its two main aspects. These aspects include: 1) volitional efforts and techniques for volitional regulation (it is mainly the subject studied in sports psychology); 2) permanent features of person's volitional activity - his/her volitional qualities.

Along with this there are still some unresolved questions of finding relevant indicators for the diagnosis of volitional capacity of the individual, and the problem of consistency of the results obtained for different levels of person's volitional activity is to be solved as well.

The subject of this study is a volitional organization of personality. We can define the volitional personality organization as a system of permanent features of volitional activity (volitional qualities), naturally linked to a particular individual. 
The purpose of the study is to consider the problem of empirical research of volitional personality organization, to analyze its structure, correlation and relationship of particular individual will qualities, and also the possibilities of reflexive methods in their study.

We can distinguish three approaches in the empirical study of volitional sphere:

1) the application of a laboratory experiment to study a volitional effort (muscular and mental) and also for some volitional peculiarities, where the core is willpower (patience, stubbornness, determination, etc.);

2) the application of a natural experiment in order to study volitional behavior under difficult conditions [the cycle of these psychological experiments is presented in V. Selivanov's psychological school (Selivanov, 1992)];

3) using questionnaires, self-reports, expert assessment in the study of volitional qualities.

The experience of applying various methods has shown that the ability to volitional effort "here and now" couldn't serve as a reliable criterion for volitional capacity of the individual "in general". The difficulties in selecting relevant diagnostic indicators of volitional characteristics are also associated with a lack of theoretical consideration of the very issue of strong-willed personality organization.

Firstly, the very concepts of volitional qualities, willful characteristics, as well as the specific features that distinguish between volitional characteristics and other permanent features of conscious behavior, are poorly defined. Usually belonging of a mental property to a volitional sphere is adopted by default, without the theoretical and experimental study of classification criteria. Therefore, it is sometimes unclear which criteria were the guide's shift for some scientists toward defining a personal quality as volitional one, like hard work and dedication (Ilyin, 2011), accuracy and flexibility (Britshin, 1989). Secondly, various authors provide different definitions for volition qualities like persistence or stubbornness, persistence or willpower, thus their meaning is uncertain. Thirdly, there is no generally accepted list of qualities that characterize a person's own volitional sphere. The following classifications show inconsistency in understanding the structure of individual volitional organization.

According to E. Ilyin's classification (Ilyin, 2011), there are two classes of volitional qualities: volitional (simple), and both moral and volitional (complex). The scientist divides simple qualities into two groups: 1) those related to purposefulness and duration of volitional effort maintenance (patience, stubbornness, persistence); 2) those that characterize self-control (courage, endurance, determination). The person's actual volitional behavior is supposed to be determined by complex moral and volitional qualities. These include independence and initiative, discipline and organization, conscience, heroism and courage, integrity and dedication.

V. Kalin (Kalin, 2011) identifies two classes (levels) of volitional qualities: basal (primary) and systemic (secondary). Basal qualities include energy, patience, endurance and courage. Such system volitional qualities as persistence, discipline, independence, purposefulness, leadership and organization, include the manifestations of both the volitional and other aspects of the psyche. 
A. Pooney (Pooney, 1977) indicates nine volitional qualities. He has separated purposefulness and brought together in pairs such qualities as determination and courage, persistence and stubbornness, independence and initiative, patience and self-control. The scientist explains that pairwise association is possible because these qualities cannot work in isolation but only being closely interconnected in the integral will expressions. All these qualities are combined into a single system by purposefulness that is defined by the person's life goals and motives.

M. Britshin (Britshin, 1989) classifies volitional qualities depending on the levels of mental management they are often involved into. The scholar has distinguished eleven levels of management and activity regulation (activity initiation, course planning, complex information processing etc.). Two to three qualities correspond to each managerial function. In some cases, this distribution is not clear, for example: courage and determination together with prudence are related to complex information processing in decision making.

This classification is an example of the broad interpretation of the will that often occurs in psychology. About a half of the twenty four will characteristics distinguished by the scientist can hardly belong to the will sphere, they are the following: diligence, foresight, quick-wittedness, soundness, circumspection, pedantry, consciousness, rationality, efficiency, accuracy, flexibility and moderation. Thus, the essence of volitional activity, its energy and emotional component are leveled: the image of a willed, strong man with his passionate desires and efforts to win and overcome can hardly be seen through the large number of administrative functions.

\section{PARTICIPANTS AND RESEARCH METHODS}

Weapplied N.Stambulova's methods (In: Ilyin, 2011, pp.320-324). They include five questionnaires (20 statements each) for the diagnosis of the following qualities: purposefulness, courage and determination, perseverance and stubbornness, initiative and independence, self-control and patience. Besides purposefulness, all volitional qualities are combined into pairs. Each technique questionnaire allows diagnosing two parameters - manifestation and generalizing. The first parameter determines the existence and stability of expressing the attributes corresponding volitional quality, the second parameter defines its universality, i.e., the latitude of its manifestations in different life situations. We chose N. Stambulova's methods because they highlighted different sides of volitional activity (target, executive, intellectual, and regulatory) and different will functions (incentive and braking).

The survey involved 77 people who are full time senior students, undergraduates and graduate students of two city universities. The statistical processing of empirical data was made using the STATISTICA 6.0 program, and methods of descriptive statistics, correlation, factor, comparative, cluster analysis have been applied. 


\section{DISCUSSION OF THE RESULTS OF THE STUDY}

Some average values of manifestation and generalization of all qualities and also values of Student's t-criterion for independent variables for the studied group are presented in table 1.

Table 1.The average values in N. Stambulova's methods scales ( $\mathrm{t}$-criterion, that is statistically significant for the level of $\mathrm{p}<0.05$, is marked with *).

\begin{tabular}{|l|c|c|c|}
\hline \multicolumn{1}{|c|}{ volitional qualities } & $\begin{array}{c}\text { values of manifestation } \\
(\max =40 \text { points })\end{array}$ & $\begin{array}{c}\text { values of } \\
\text { generalization } \\
(\max =40 \text { points })\end{array}$ & t-criterion \\
\hline purposefulness & 30.28 & 28.22 & $2.609^{*}$ \\
\hline courage and determination & 23.90 & 25.03 & -0.306 \\
\hline $\begin{array}{l}\text { persistence and } \\
\text { stubbornness }\end{array}$ & 28.01 & 27.17 & 0.948 \\
\hline $\begin{array}{l}\text { initiative and } \\
\text { independence }\end{array}$ & 25.91 & 23.31 & $2.736^{*}$ \\
\hline self-control and endurance & 25.18 & 23.99 & 1.433 \\
\hline
\end{tabular}

Source: Own research.

Manifestation values are supposed to be higher than those of generalization for all qualities except courage and determination. Statistically significant differences between these values (for $\mathrm{p}<0.05$ ) are found for the scales of purposefulness, initiative and independence.

The values of generalization reflect the ability to detect a certain volitional quality in different life situations and activities (training, sports, social activities, communication, etc.). Let us consider purposefulness. Can a strong-willed person be expected to show the same purposefulness in different activity areas? Purposefulness provides a clear definition of the goal and ways to achieve it. Usually we mean a far-reaching goal requiring some efforts over a long period of time, sustained motivation and interest in certain activities. A precise definition of qualities should prevent dispersion of efforts for other types of activity.

The question concerning the universality of the certain volitional quality and its identity in various activities arises in this context. In studies conducted by V. Selivanov's school (Selivanov, 1992. pp. 150 - 154), students in rural schools were shown to express willpower differently in training and at work. So-called «theorists» showed persistence, initiative, and also resistance to difficulties during lessons and when doing homework. However, they appeared to be sluggish and weak-willed at home and work. And vice versa, «practical people» showed volitional behavior outside the classroom instead of school. Unfortunately, these interesting results have remained unnoticed by further researches.

Compared to other qualities, purposefulness and persistence received the highest scores both in terms of manifestation and generalization.

The lowest scores are obtained on the scale of the basal qualities like courage and determination, self-control and endurance. Measuring basal volitional quali- 
ties using questionnaires generally causes the greatest caution. Nevertheless, lower scores on these scales compared to the system qualities scales show a certain degree of realistic self-esteem of the people who were investigated.

Some differences by gender are revealed in test results. The study involved 45 women and 32 men. The total score for each scale and Student's t-criterion for independent samples beside the values of manifestation and generalization are presented in table 2 .

The girls appeared to be more independent and initiative than the boys (difference statistically significant for $\mathrm{p}<0.05$ ). They also exceed the boys in all values of generalization, i.e., concerning the latitude of volitional qualities manifestation in various activities. The values of manifestation indicate that the girls concede to the boys an expression intensity of basal qualities like courage and self-control, while girls' generalization values on the same scales seem to be higher.

Volitional personality structure varied in their nature and functions qualities, sometimes quite contradictory ones, such as courage and patience that develop on the different neural basis. In some cases typological complex will strengthen bravery, but unrestrained behavior, in other cases - patient and careful. Every person is characterized by a unique combination of volitional qualities that provide volitional activity at a certain level. Lack of some qualities is compensated by the development of others. Cluster analysis allows identifying the options for this combination.

Table 2. Differences by gender in test results ( $t$-criterion, that is statistically significant for the level of $\mathrm{p}<0.05$, is marked with *)

\begin{tabular}{|c|c|c|c|}
\hline volitional qualities & women & men & $\mathrm{t}$-criterion \\
\hline \multicolumn{4}{|c|}{ values of manifestation ( $\max =40$ points) } \\
\hline purposefulness & 30.20 & 30.38 & -0.156 \\
\hline courage and determination & 23.58 & 24.34 & -0.585 \\
\hline persistence and stubbornness & 28.24 & 27.69 & 0.444 \\
\hline $\begin{array}{l}\text { initiative and } \\
\text { independence }\end{array}$ & 27.29 & 23.97 & $2.674^{*}$ \\
\hline self-control and endurance & 24.67 & 25.91 & -1.010 \\
\hline \multicolumn{4}{|c|}{ values of generalization ( $\max =40$ points) } \\
\hline purposefulness & 29.42 & 26.53 & $2.623^{*}$ \\
\hline courage and determination & 25.42 & 24.47 & 0.809 \\
\hline persistence and stubbornness & 27.89 & 26.26 & 1.332 \\
\hline $\begin{array}{l}\text { initiative and } \\
\text { independence }\end{array}$ & 24.24 & 22.00 & 1.586 \\
\hline self-control and endurance & 24.36 & 23.47 & 0.760 \\
\hline \multicolumn{4}{|c|}{ total score ( $\max =80$ points) } \\
\hline purposefulness & 59.27 & 56.63 & 1.321 \\
\hline courage and determination & 49.07 & 49.41 & -0.153 \\
\hline persistence and stubbornness & 56.11 & 54.38 & 0.737 \\
\hline $\begin{array}{l}\text { initiative and } \\
\text { independence }\end{array}$ & 51.76 & 46.34 & $2.390^{*}$ \\
\hline self-control and endurance & 48.98 & 49.34 & -0.171 \\
\hline
\end{tabular}

Source: Own research. 
On the basis of the hierarchy classification dendrogram and K-means method, three clusters of those under study have been outlined (see Fig.1). The values of manifestation are the subjects of clustering, as they reflect the main features of volitional qualities.

Fig.1. Graphs of mean indices for each cluster:

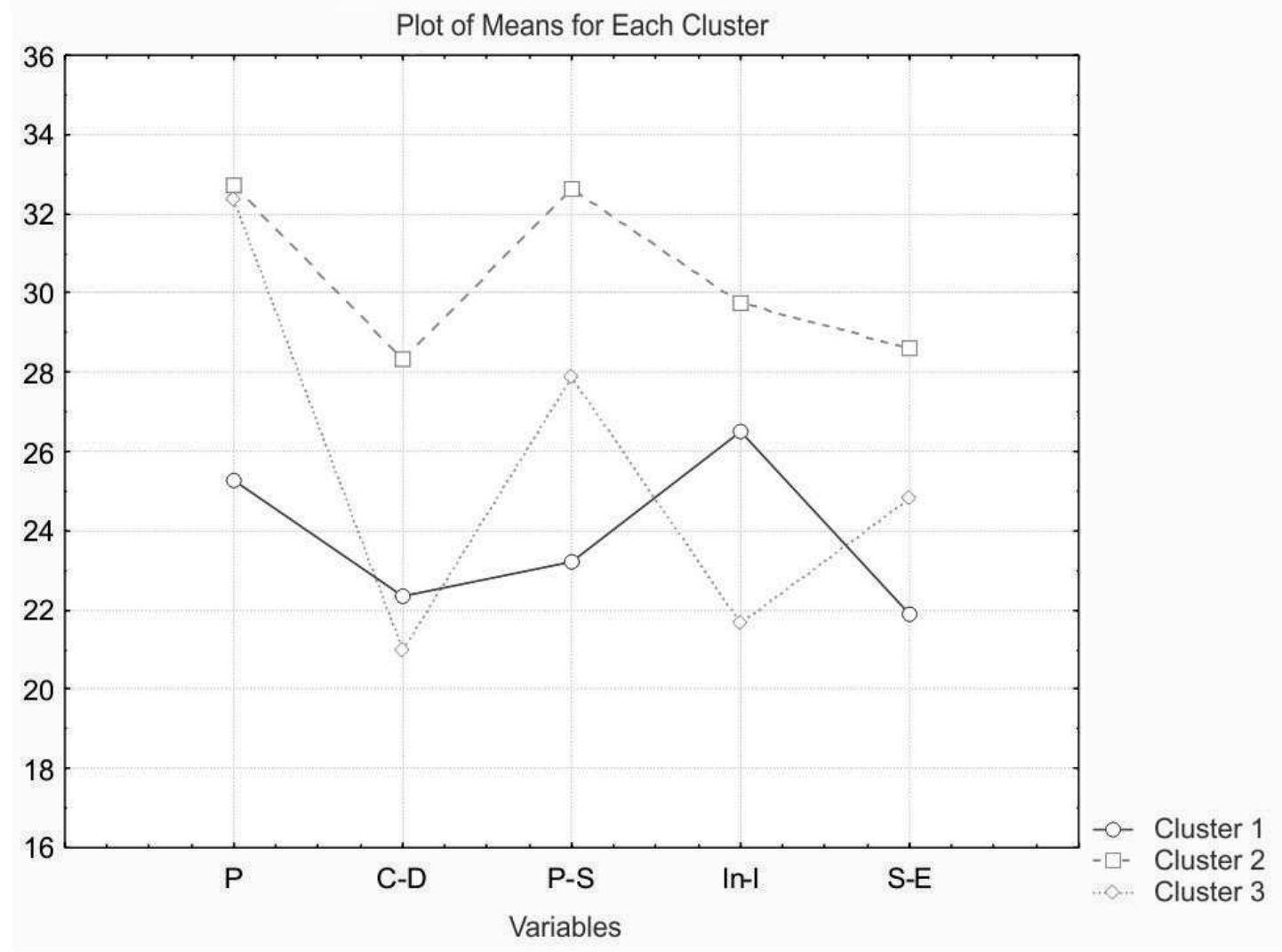

P - purposefulness, C-D - courage and determination, P-S - persistence and stubbornness, In-I initiative and independence, S-E - self-control and endurance.

Source: Own research.

There are 24 people in cluster 1 ; there are more girls in it (71\%), the number of boys is much smaller $(29 \%)$. It is characterized by the lowest indicators of self-control, persistence and purposefulness; initiative is noted on the background of these indicators. Conventionally, this cluster can be called "Initiative, not willful."

Cluster 2 has the highest rates on all scales with the peaks on the scales of purposefulness and persistence compared to other clusters. This cluster can be marked as "Strong-willed, purposeful and persistent." There are 26 people in it (62\% girls and $38 \%$ boys).

Cluster 3 is characterized by a somewhat controversial combination of qualities and an unexpected composition of people being investigated: a total of 27 people, including more than a half of the boys (55\%)! A zigzag profile with peaks at purposefulness and persistence and sharp dips in the scales of courage and initiative shows that this cluster can be called "Purposeful, but timid and inert". 
We analyzed relationships between scale indicators of N. Stambulova's methods. A correlation matrix (table 3) indicates the tight connection between almost all test scales at $\mathrm{p}<0.01$.

Table 3. Correlation matrix: the correlations that are not statistically significant for $\mathrm{p}<0.01$ are provided in brackets

\begin{tabular}{|c|c|c|c|c|c|c|c|c|c|c|}
\hline & $\mathrm{P}$ & C-D & P-S & In-I & S-E & $\mathrm{P}_{\mathrm{g}}$ & C-D ${ }_{g}$ & $\mathrm{P}-\mathrm{S}_{\mathrm{g}}$ & In-I $I_{g}$ & S-E \\
\hline $\mathrm{P}$ & 1,00 & & & & & & & & & \\
\hline C-D & 0,31 & 1,00 & & & & & & & & \\
\hline P-S & 0,62 & 0,36 & 1,00 & & & & & & & \\
\hline In-I & $(0,17)$ & 0,34 & 0,32 & 1,00 & & & & & & \\
\hline S-E & 0,40 & 0,42 & 0,52 & 0,34 & 1,00 & & & & & \\
\hline $\mathrm{P}_{\mathrm{g}}$ & 0,49 & 0,37 & 0,51 & 0,38 & 0,30 & 1,00 & & & & \\
\hline $\mathrm{C}-\mathrm{D}_{\mathrm{g}}$ & 0,48 & 0,51 & 0,47 & 0,37 & 0,37 & 0,44 & 1,00 & & & \\
\hline P-S & 0,52 & 0,31 & 0,66 & 0,41 & 0,41 & 0,61 & 0,46 & 1,00 & & \\
\hline In-I $I_{g}$ & 0,40 & 0,45 & 0,46 & 0,56 & 0,48 & 0,63 & 0,45 & 0,61 & 1,00 & \\
\hline S-E & 0,40 & $(0,24)$ & 0,54 & $(0,12)$ & 0,50 & $(0,29)$ & 0,33 & 0,41 & $(0,28)$ & 1,00 \\
\hline
\end{tabular}

Source: Own research.

We will call the scales according to the first quality for the ease of description. The closest correlations is between persistence and purposefulness both according to main features $(\mathrm{r}=0.62)$, and in various areas of activity as generalized qualities $(r=0.61)$. Persistence is generally considered to be the leader of correlations.

There seem to be no statistically significant correlation between the initiative and purposefulness $(r=0.17)$, while there is a high correlation between the same properties as generalized volitional qualities $(\mathrm{r}=0.63)$.

On the one hand, a tight correlation matrix may be an argument in favor of correlation of all qualities, at least functional one, as the key task for all will manifestations is to overcome various obstacles in difficult situations. On the other hand, a strong correlation between the scales of the questionnaire may have other reasons: 1) the allocation of specific features as separate volitional qualities and volitional regulation in general are still unclear in comparison with arbitrary self-regulation; 2) the particular construction techniques.

The four questionnaire scales combine two volitional qualities each. Although these qualities are closely interconnected, they have their own specific characteristics. Is it legitimate to have a combination of courage and determination, initiative and independence? An independent person is not necessarily a initiative one. A decisive person is not always courageous, because courage overcomes fear (including that associated with the risk for health and life) and determination conquers fluctuations regarding the correctness of decisions. The correlation between purposefulness and persistence as leading volitional behavior qualities also needs a detailed consideration.

A factor analysis using the method of principal components with Varimax rotation has been applied. Concerning Kaiser and Kettell criteria, we have selected two factors (60.2\% contribution to the total variance). 
Factor 1 (48.7\% of variance) includes scales of initiative (factor loading is 0.81 ), initiative and purposefulness as generalized qualities (factor loading is 0.79 and 0.65 , respectively), and courage (factor loading is 0.61 ). We can call this factor "Initiative".

Factor 2 ( $11.57 \%$ of the total variance) is made of the following scales: self-control as a generalized quality (0.82), persistence (0.78), purposefulness (0.73), and self-control (0.61). Initiative and courage represent the lowest loading. We can call this factor "Willpower, persistence". Here you can find qualities that help a person achieve a difficult long-term goal.

The scale of initiative and independence stands separately in this factor distribution. These qualities are less characterized by specific volitional qualities the fact of using will efforts in order to overcome external or internal barriers. Of course it is difficult to imagine a strong-willed person to be dependent and inert, although the initiative and independence characterize both volitional and arbitrary behavior. Independence is a necessary feature of the adult, mature man.

E. Ilyin classifies independence and initiative as complex moral and volitional qualities. Independence is the desire and ability to perform any activity without assistance (Ilyin, 2011).

You can argue with scientists about considering initiative as a separate case of independence.

Initiative is the driving force for any undertaking. It represents the energy that helps a person dare to start a new business and introduce new solutions. It is related to determination and courage (this explains the high loading of the first factor in «courage, determination» scale). Initiative generally is a diverse quality; there is a lot of creativity, spontaneity, desire, and entrepreneurship. Purposefulness cannot exist without initiative.

The first factor, «Initiative», can seem to be quite a symbolic one as concentrating power in the early promotion to the goal, the initiative is not responsible for this activity completion. The implementation is carried out by the real volitional qualities that are combined by the second factor «Willpower».

Let us consider in more detail these «real» volitional qualities. The results focused on the scales for purposefulness and persistence are highly correlated. The content of these concepts has much in common. Purposefulness is related to the ability to set clear goals (usually advanced, long-term) and to subordinate all its activities to achieving these goals. Purposefulness is a value-semantic component of volitional activity that provides consistently high level of motivation and willingness to act. In N. Stambulova's questionnaire the ability to set goals, plan the activity, implement it despite the failures, and complete the activity are stressed. The questions seem to be generalized.

Persistence is particularly more important. The goal is assumed a priori to have been already defined. The very process of its achieving and the ability to use willpower continuously in order to overcome obstacles are highlighted. Although stubbornness has its own specific features, the questionnaire puts persistence and stubbornness into one scale. Stubbornness involves the concentration of volitional effort «here and now» to achieve a short-term goal. Persistence has a long-term 
effect, while stubbornness is characterized by a short-term influence. The issues of «persistence - stubbornness» scale emphasize on the ability to perform activities systematically and consistently, to overcome fatigue and boredom, to complete the activity, and to defend the position.

There is a high correlation between the scales for «persistence - stubbornness» and «self-control - endurance». We can define self-control as the ability to control somebody's behavior in any situation; endurance is considered to be the basis for its formation (Selivanov, 1992). Endurance is the ability to slow down or weaken quickly the excessive psychical activity, deter and suppress unnecessary current feelings, thoughts and habits (Kalin, 2011, p. 39). Self-control is considered to be a common characteristic of volitional behavior that includes endurance, courage and partly determination, i.e. those volitional qualities that are associated with the suppression of negative emotions and unwanted incentives (Ilyin, 2011, p. 187).

Some issues of N. Stambulova's methods represent a person's ability to control his/her thoughts, feelings, actions in different difficult situations, to endure pain, overcome impatience and excitement, and restrain emotional reactions.

Table 4 provides the results of the volitional qualities analysis according to the basic, mandatory signs of the volitional process: 1 ) the availability of a conscious goal; 2) the availability of obstacles to be overcome; 3 ) the availability of volitional effort. The table also indicates which volitional function (incentive or braking) is performed by the relevant quality.

Empty columns in the table mean that it is difficult to specify a particular parameter; however that does not mean that the quality is not represented. For example, a purposeful person can face different kinds of obstacles and difficulties when achieving strategic goals. Various volitional qualities like persistence, courage, determination, etc. with activating the appropriate volitional effort at a certain level or without it, are required to overcome these obstacles.

Table 4. The signs of volitional qualities.

\begin{tabular}{|c|c|c|c|c|}
\hline $\begin{array}{l}\text { volitional } \\
\text { qualities }\end{array}$ & goal characteristic & $\begin{array}{l}\text { will effort } \\
\text { characteristic }\end{array}$ & $\begin{array}{l}\text { the obstacle } \\
\text { that must be } \\
\text { overcome }\end{array}$ & $\begin{array}{l}\text { volitional } \\
\text { function }\end{array}$ \\
\hline purposefulness & $\begin{array}{l}\text { well defined, } \\
\text { perspective }\end{array}$ & & & incentive \\
\hline courage & $\begin{array}{l}\text { determined, } \\
\text { short-term }\end{array}$ & \begin{tabular}{|l|} 
strongly \\
determined, \\
applied „here and \\
now"
\end{tabular} & $\begin{array}{l}\text { fear, danger to } \\
\text { life and health }\end{array}$ & incentive \\
\hline determination & well defined & $\begin{array}{l}\text { applied "here and } \\
\text { now" }\end{array}$ & $\begin{array}{l}\begin{array}{l}\text { doubt, hesitation, } \\
\text { uncertainty }\end{array} \\
\end{array}$ & incentive \\
\hline persistence & $\begin{array}{l}\text { well defined, } \\
\text { long-term }\end{array}$ & $\begin{array}{l}\text { volitional efforts } \\
\text { have been applied } \\
\text { throughout the } \\
\text { period of the goal } \\
\text { achieving }\end{array}$ & \begin{tabular}{|l|} 
fatigue, \\
frustration, \\
boredom, laziness
\end{tabular} & incentive \\
\hline
\end{tabular}




\begin{tabular}{|c|c|c|c|c|}
\hline stubbornness & short-term & \begin{tabular}{|l|} 
clearly \\
determined, \\
applied „here and \\
now”
\end{tabular} & \begin{tabular}{|l} 
fatigue, \\
frustration, \\
resistance of \\
others \\
\end{tabular} & incentive \\
\hline initiative & $\begin{array}{l}\text { short-term or } \\
\text { long-term }\end{array}$ & $\begin{array}{l}\text { maybe present at } \\
\text { the beginning of } \\
\text { the activity }\end{array}$ & $\begin{array}{l}\text { rigidity, laziness, } \\
\text { passivity }\end{array}$ & incentive \\
\hline independence & & & $\begin{array}{l}\text { dependence, } \\
\text { helplessness }\end{array}$ & \\
\hline endurance & & $\begin{array}{l}\text { strongly } \\
\text { determined, } \\
\text { applied „, here and } \\
\text { now" }\end{array}$ & $\begin{array}{l}\text { impulsiveness, } \\
\text { impatience, } \\
\text { anger and } \\
\text { other negative } \\
\text { emotions, pain }\end{array}$ & braking \\
\hline self-control & & $\begin{array}{l}\text { behavior control } \\
\text { that can turn into } \\
\text { will effort }\end{array}$ & $\begin{array}{l}\text { the same as in the } \\
\text { case of endurance }\end{array}$ & braking \\
\hline
\end{tabular}

Source: Own research.

The obstacles to the qualities that represent inhibitory will function (self-control and endurance) are obvious; however in this case it is difficult to identify a specific goal. The most difficult is to specify all the will parameters for independence.

Persistence, stubbornness and endurance can act as an effective and convenient model for studying the actual volitional behavior, including by means of questionnaires.

Courage is a clear manifestation of the person's willpower. Experimental study of this quality is complicated by a number of reasons, including the need to create a situation of real danger and take into account individual peculiarities in the occurrence of fear. Courage is quite often associated with fear, insensitivity to a threatening situation. The real courage is manifested when a person feels fear in dangerous situations, but overcomes it with volitional efforts and continues to perform the required actions. An extremely strong emotional charge of this property limits its study using questionnaires, although such an attempt was made in this research.

\section{CONCLUSIONS}

The person's will organization is represented by a wide range of volitional qualities. Various authors mostly often refer to the purposefulness, determination, persistence, endurance, independence, courage, self-control and initiative. Most of these qualities represent incentive volitional function and have a complex structure, i.e., they combine containing valuable, moral, intellectual and emotional components together with the mandatory volitional component.

The lack of theoretical consideration of the very issue of strong-willed personality organization, the lack of clear and unambiguous representations of the core, key features of the person's volitional capacity causes some difficulties in selecting methods for its diagnosis. 
In this research we have made an attempt to analyze in detail the possibilities of the survey method in the study of the structure of the person's will organization.

We have revealed some differences according to the gender in the structure of volitional organization, and also some differences in the manifestation of volitional qualities depending on the scope of activity. Correlative and factor analysis showed a close relationship among scales for persistence and purposefulness, as well as the relative independence of the scale for initiative from the other scales of these methods.

Cluster analysis identified several options for the combination of volitional properties; further work in this area will help identify certain types of volitional personality organization. Special attention should be paid to the ratio of basal and system volitional qualities of the particular person.

The study conducted has revealed a number of problems associated with the use of the survey methods. Tight correlations between the scales of the questionnaire may indicate a system error in the construction of these techniques -the lack of elaboration of specific features that would distinguish one volitional quality from another.

To improve the efficiency of testing it is necessary to conduct a qualitative analysis of particular volition qualities, their clear distinction, the kind of "inventory" for the presence of mandatory volitional parameters. In order to clarify some diagnostic features we should also consider the nature of the obstacles, the presence and specificity of the volitional effort, the peculiarities of a certain volitional quality manifestation in various areas of activity like physical, intellectual, and communicative.

\section{REFERENCES}

Britshin, М. (1989). Воля и волевые качества личности [Will and volitional qualities of personality]. In: B.F. Lomov,\& K.A. Abulhanova (Eds.) Психология личности в соииалистическом обществе [Psychology of Personality in a socialist society] (pp.134 - 144). Moscow: Московский государственный университет (МГУ) .

Ilyin, Y. P. (2011). Психология воли [Psychology of will]. Saint Petersburg: Питер.

Ivannikov, V. A. (2010). Воля [Volition]. Национальный психологический журнал, 1(3), 97 - 102.

Kalin, V. K. (2011). Классификаиия волевых качеств [Classification volitional qualities]. In: V. K. Kalin (Ed.), Психология воли: сборник научных трудов [Psychology of will: collection of scientific labours] (pp.36 - 43). Simferopol: Таврический национальный университет (ТНУ)

Pooney, А. С. (1977). Психологические основы волевой подготовки в спорте [Psychological foundations of a volitional training in sport]. Moscow: Физкультура и спорт.

Selivanov, V. I. (1992). Избранные психологические произведения: воля, её развитие и воспитание [Selected psychological works: the will, its development and education]. Ryazan: Рязанский государственный педагогический институт.

Smirnov, B. N. (2004). О разных подходах к проблеме воли в психологии [On the different approaches to the problem will in psychology]. Вопросы психологии, 3, $64-70$. 